\title{
OPEN
}

\section{Author Correction: A distinct and active bacterial community in cold oxygenated fluids circulating beneath the western flank of the Mid-Atlantic ridge}

Julie L. Meyer, Ulrike Jaekel, Benjamin J. Tully, Brian T. Glazer, C. Geoffrey Wheat, Huei-Ting Lin, Chih-Chiang Hsieh, James P. Cowen, Samuel M. Hulme, Peter R. Girguis \& Julie A. Huber

Correction to: Scientific Reports https://doi.org/10.1038/srep22541, published online 03 March 2016

This Article contains an error in Table 1. For the Oxygen concentration of the seawater sample, " 240" should read “ 250".

\begin{abstract}
(c) (i) Open Access This article is licensed under a Creative Commons Attribution 4.0 International License, which permits use, sharing, adaptation, distribution and reproduction in any medium or format, as long as you give appropriate credit to the original author(s) and the source, provide a link to the Creative Commons license, and indicate if changes were made. The images or other third party material in this article are included in the article's Creative Commons license, unless indicated otherwise in a credit line to the material. If material is not included in the article's Creative Commons license and your intended use is not permitted by statutory regulation or exceeds the permitted use, you will need to obtain permission directly from the copyright holder. To view a copy of this license, visit http://creativecommons.org/licenses/by/4.0/.
\end{abstract}

(C) The Author(s) 2020 